\title{
MAASTRICHTIAN LARGER BENTHIC FORAMINIFERA FROM THE ARABIAN PLATE SENSU LATO: NEW DATA FROM SOMALIA, TURKEY, AND IRAN
}

\author{
Felix Schlagintweit
}

Received: 12 April 2020 / Accepted: 13 May 2020 / Published online: 18 May 2020

\begin{abstract}
Larger benthic foraminifera from the upper Maastrichtian Auradu Formation of Somalia exhibit striking matches with the assemblages from the time-equivalent Tarbur Formation of Iran and other, but less well studied lithostratigraphic units in SE Turkey (e.g., Garzan Fm.). Some taxa, among also new ones, described from Somalia need taxonomic updates (revision, synonymy, re-instatement). Dukhania? cherchii Luger is considered a junior synonym of Acordiella? tarburensis Schlagintweit \& Rashidi, and Pseudorbitolina schroederi Luger is re-instated and considered a valid taxon, different from the Campanian P. marthae Douvillé of the western Tethyan domain. The genus Cyclopsinella Galloway is reported for the first time from the upper Maastrichtian of Iran.
\end{abstract}

Keywords: Upper Cretaceous, Somaliland, Anatolia, Middle East, larger benthic foraminifera

\section{INTRODUCTION}

In 2014 Peter Luger, having finished (but not publicated) his habilitation thesis at the University of Berlin passed away. Four years later his work was finally published entitled "Micropalaeontology (Foraminiferida, Ostracoda), biostratigraphy and facies development of the Cretaceous of Northern Somalia including a contribution concerning the geodynamic development of eastern Gondwana during the Cretaceous to basal Paleocene". It was published in German in the series Documenta Naturae Abhandlungen dated $6^{\text {th }}$ of December 2018 with two volumes, text (part 1, 370 pages), and plates (part 2, 49 plates). Both volumes are available online (https://www.amh-geo.com/startseite/fachzeitschriften /doc-nat-abhandlungen). The studied strata include Lower Cretaceous (Aptian) to Early Paleogene formations of northern Somalia. It is worth mentioning that in the last years the rift basin at the northern part of Somalia ("Somaliland"), located at the horn of Africa, got into the focus for oil exploration activities (Ali, 2006, 2015; Davidson et al., 2018). The Auradu Limestone Formation (or Auradu Formation), a thick shallow-water carbonate succession, was previously believed to be exclusively of Paleogene age (e.g., Carbone et al., 1993). A late Maastrichtian age for the lower part of the Auradu Formation was evidenced by Cherchi et al. (1993), noting the occurrence of the large benthic foraminifera (LBF) Loftusia and Omphalocyclus. The plates of LBF by Luger (2018) from the upper Maastrichtian part of the Auradu Formation show similarities to time-equivalent assemblages reported from the Tarbur Formation of SW Iran (Zagros Zone), investigated by the present author in recent years (e.g., Schlagintweit et al., 2016a, b). As the work of Luger (2018) also includes new species, the present paper provides a taxonomic review of some of the taxa (preferentially agglutinating forms). The present compilation is supplemented by some data from SE Turkey (e.g., Meriç, 1974a, b; Köylüoğlu, 1986; Çoruh et al., 1997, e.g. Garzan Formation), that geotectonically belongs to the northernmost part of the Arabian Plate (e.g., Özer et al., 2009, Fig. 1). In this region, the Garzan Formation is a regional important oil reservoir, with the Garzan field east of Batman City as its type-locality (e.g., Temple and Perry, 1962; Ala and Moss, 1979; Yildizel, 2008). Other occurrences of Maastrichtian shallow-water carbonates with rich assemblages of LBF are known from Iraq (Tanjero Formation, Aqra Limestone), Qatar, Oman (Simsima Formation), and Saudi Arabia (Aruma Formation) (e.g., Barrier and Vrielynck, 2008) (Fig. 1).

\section{SOME REMARKS ON MAASTRICHTIAN SUBSTAGES AND BIOSTRATIGRAPHY}

Biostratigraphy of Maastrichtian shallow-water carbonates is mainly based on the vertical distribution of the larger benthic foraminifera (e.g., Wynd, 1965: Tarbur Formation of Iran). that sometimes has been tentatively calibrated using the occurrence of some associated planktonic foraminifera (see e.g. Robles-Salcedo et al., 2019 and Consorti and Köroğlu, 2019 among the most recent literature). Whereas the total duration of the Maastrichtian stage is well known $(6.15 \pm 0.05 \mathrm{Ma}$ acc. to Thiebault et al., 2012), there are still contrasting views on its subdivisons (two-fold or three-fold), and their respective time frames (Fig. 2 above). The common subdivision differentiates the Maastrichtian into two substages, lower and upper although there is no agreement on the boundary criterion (see Ogg and Hinnov, 2012). The different usage makes it problematic to subsequent workers placing in context, for instance, a taxon said to be restricted to the middle Maastrichtian, e.g. some Loftusia species (see Meriç and Görmüş, 2001, Fig. 2a). It is noteworthy here that the monographic work of Meriç and Görmüş (2001, fig. 7) includes 15 species, each indicated with a distinct stratigraphic distribution (lower, middle, upper Maastrichtian). In this context, especially the occurrence of the nearly cosmopolitan siderolitids, namely Siderolites calcitrapoides Lamarck and Canalispina iapygia Robles-Salcedo et al., in or closely related to Loftusia-bearing strata is noteworthy. Both species are restricted to the upper Maastrichtian (Robles- 


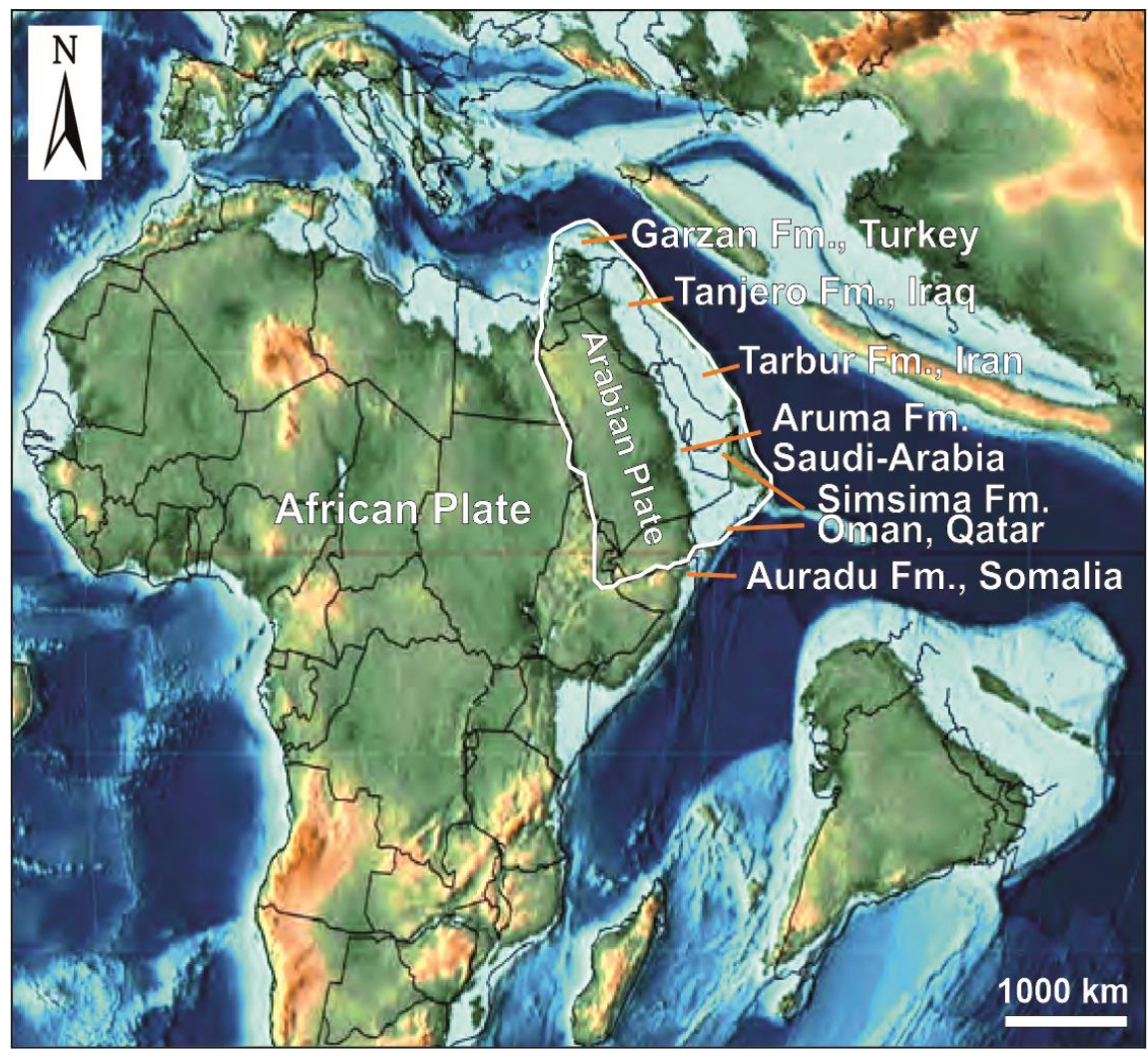

Fig. 1 Distribution of Maastrichtian shallow-water carbonates along the margins of the northern Arabic and northeastern African plates (modified from Scotese, 2001). For lithostratigraphy and distribution see Barrier and Vrielynck, 2008).

Salcedo et al., 2018, 2019). C. iapygia and S. calcitrapoides have been reported from several sections of the Tarbur Formation, preferentially in the lower part (Schlagintweit and Rashidi, 2016; Consorti et al., 2019; Septfontaine et al., 2019), commonly associated with Omphalocyclus/Pseudomphalocyclus, more rarely with Orbitoides, and Pseudedomia hamaouii Rahaghi. Already Cox (1937) reported that in Iran, species of Loftusia are frequently associated with Omphalocyclus macroporus Lamarck and Siderolites Lamarck. For the Tarbur Formation, Wynd (1965) established a OmphalocyclusLoftusia assemblage zone of Maastrichtian age (including also the basal Sachun Formation) with, among others, Siderolites as typical accompanying taxon (Wynd, 1965, pl. $25 \mathrm{~b}$ Siderolites $=$ Canalispina iapygia $)$. Within the Omphalocyclus-Loftusia assemblage zone, Wynd (1965) differentiated an upper, Elphidiella multiscissurata subzone. This taxon has been taxonomically revised by Consorti et al. (2019) becoming Palaeoelphidium multiscissuratum (Smout) (Fig. 2 below). In this Palaeoelphidium multiscissuratum subzone (new name!), also the occurrence of siderolitids has been mentioned by Wynd (1965) documenting its upper Maastrichtian age (see discussion in Schlagintweit et al., 2016a). For the two siderolitids $S$. calcitrapoides and S. denticulatus, RoblesSalcedo et al. (2018, fig. 20) postulated the range of both up to the $\mathrm{K} / \mathrm{Pg}$ boundary encompassing the Pseudoguembelina hariaensis and Plummerita hantkeninoides planktonic foraminifera zones. At least for the former zone, the occurrence of Siderolites is verified (e.g., Schlagintweit et al., 2016c).

\section{MATERIAL AND METHODS}

The present paper represents a compilation of some larger benthic foraminifera using own material from the Tarbur Formation of Iran, and literature illustrations from the Auradu Formation of Somalia, and the Garzan Formation of Turkey (Table 1). In the provided synonymy list other occurrences are also included. The material from the Tarbur Formation comes from the following three sections Fasa section (Folded Zagros Belt): see Rashidi and Schlagintweit (2019). For overall geological setting see also Piryaei et al. (2010)

Mandegan section (High Zagros Belt): see Schlagintweit and Rashidi (2016)

Naghan section (Folded Zagros Belt): see Schlagintweit and Rashidi (2016), and Rashidi and Schlagintweit (2018).

\section{MICROPALAEONTOLOGY}

As only remarks are provided (no systematic descriptions), the considered taxa are treated in alphabetical order (leaving apart the suprageneric status). The synonymy includes information of the lithostratigraphic occurrences.

Accordiella? tarburensis Schlagintweit \& Rashidi 2016 Fig. 3a-b

*2016 Accordiella? tarburensis n. sp. - Schlagintweit and Rashidi, p. 54, fig. 5a pars, 6-7, 8 pars (late Maastrichtian Tarbur Formation of Iran). 


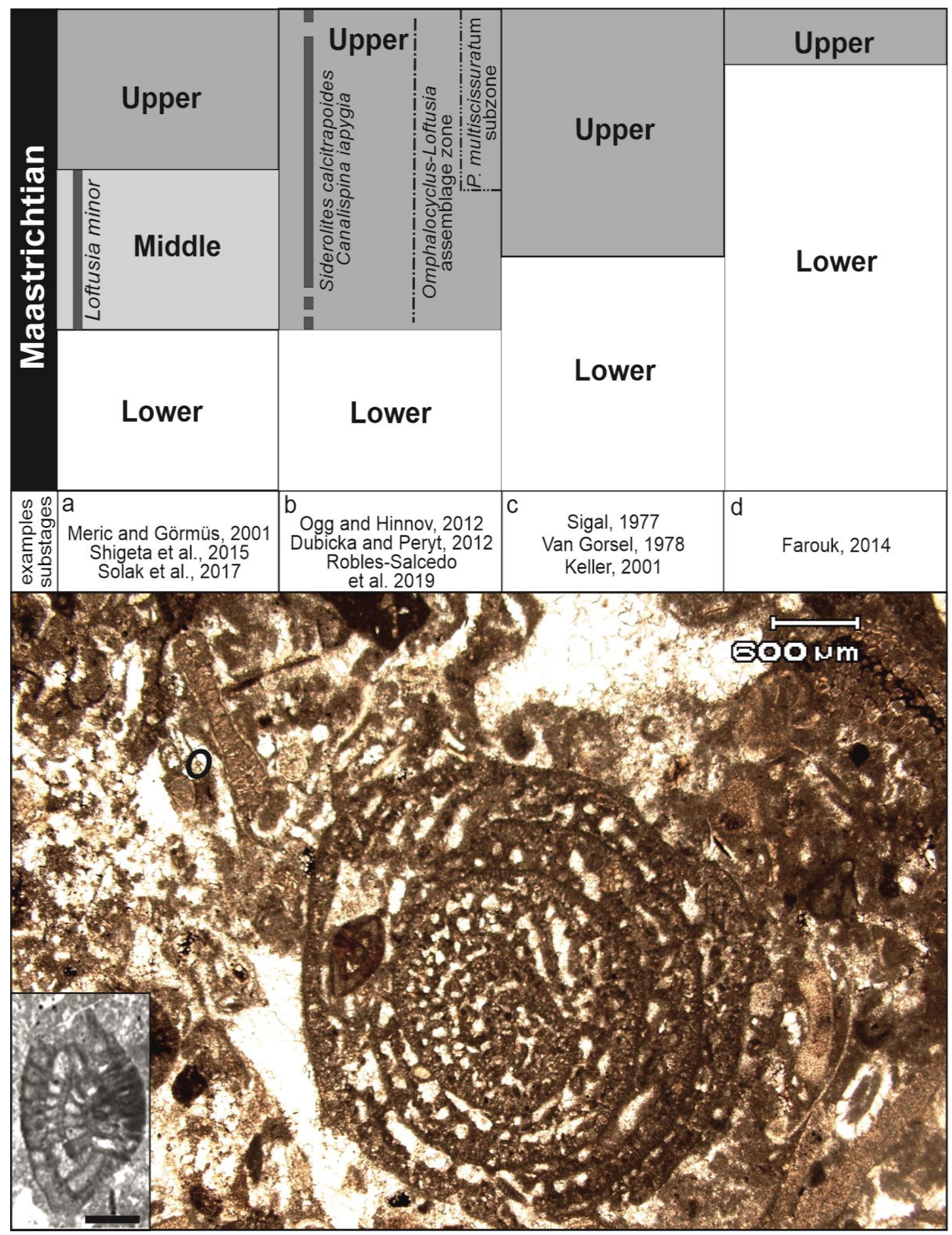

Fig. 2 Above: Subdivison of the Maastrichtian stage: comparison of different used substages and biostratigraphic use of selected larger benthic foraminifera. Examples: Loftusia minor (acc. to Meriç and Görmüş, 2001), Siderolitidae (acc. to Robles-Salcedo et al., 2018, 2019), and relationship to biozonation of Wynd (1965) (modified herein). Below: Example of the Palaeoelphidium multiscissuratum subzone (new name) of the Omphalocyclus-Loftusia assemblage zone sensu Wynd (1965), upper Maastrichtian Tarbur Formation, SW Iran. Loftusia sp. in the middle with agglutinated test of Palaeoelphidium multiscissuratum (Smout) (detail from Luger, 2018, pl. 26, fig. 10, illustrated as Laffiteina aff. jaskii Rahaghi), and Omphalocyclus $(O)$. 
Table 1 Distribution of the Maastrichtian (mostly larger) benthic foraminifera treated in the present compilation (for references see synonymy for each taxon).

\begin{tabular}{|l|l|l|l|l|}
\hline \multicolumn{1}{|c|}{ Formation, area } & $\begin{array}{l}\text { Auradu Fm } \\
\text { Somalia }\end{array}$ & $\begin{array}{l}\text { Simsima Fm. } \\
\text { Qatar }\end{array}$ & $\begin{array}{l}\text { Tarbur Fm. } \\
\text { SW Iran }\end{array}$ & $\begin{array}{l}\text { Garzan } \\
\text { equivalent Fm. } \\
\text { SE Turkey }\end{array}$ \\
\hline Accordiella? tarburensis & $\mathbf{X}$ & & $\mathbf{X}$ & \\
\hline Antalyna korayi & $\mathbf{X}$ & & $\mathbf{X}$ & $\mathbf{X}$ \\
\hline Broeckinella arabica & & $\mathbf{X}$ & $\mathbf{X}$ & $\mathbf{X}$ \\
\hline Broeckinella grandis & & & $\mathbf{X}$ & \\
\hline Canalispina iapygia & & & $\mathbf{X}$ & $\mathbf{X}$ \\
\hline Cyclopsinella steinmanni & $\mathbf{X}$ & & $\mathbf{X}$ & $\mathbf{X}$ \\
\hline Dictyoconella? minima & & $\mathbf{X}$ & $\mathbf{X}$ & \\
\hline Dictyoconella complanata & $\mathbf{P}$ & $\mathbf{X}$ & $\mathbf{X}$ & \\
\hline Dictyoconus bahktiari & $\mathbf{X}$ & $\mathbf{X}$ & $\mathbf{X}$ & \\
\hline Gen. et sp. indet. & $\mathbf{X}$ & & $\mathbf{X}$ & $\mathbf{X}$ \\
\hline Gyroconulina columellifera & $\mathbf{X}$ & & $\mathbf{X}$ & $\mathbf{X}$ \\
\hline $\begin{array}{l}\text { Palaeoelphidium multiscis- } \\
\text { surata }\end{array}$ & $\mathbf{X}$ & $\mathbf{X}$ & $\mathbf{X}$ & \\
\hline Pseudedomia hamaouii & $\mathbf{X}$ & & $\mathbf{X}$ & $\mathbf{X}$ \\
\hline Pseudorbitolina schroederi & $\mathbf{X}$ & $\mathbf{X}$ & $\mathbf{X}$ & $\mathbf{X}$ \\
\hline
\end{tabular}

2018 Dukhania? cherchii n. sp. - Luger, p. 88, pl. 13, 67, non 9 (= Gyroconulina columellifera), 10-11 (late Maastrichtian Auradu Formation of Somalia).

Remarks: From the lower Auradu Formation, Luger (2018) established a new species as Dukhania? cherchii (Fig. 3b), that is considered a junior synonym of Accordiella? tarburensis (Fig. 3a). The maximum test height is up to $1.8 \mathrm{~mm}$ for the Somali, and up to $1.4 \mathrm{~mm}$ for the Iranian specimens. In both cases, the generic identity of the described species was indicated with some doubts (Accordiella Farinacci, family Pfenderinidae: triserial, with endoskeletal plates and pillars; Dukhania Henson, family Chrysalidinidae: triserial becoming biserial, with endokeletal pillars, see Loeblich and Tappan 1988). Because of its marginally strongly overlapping chambers, and the extensive endoskeleton consisting of numerous pillars, Dukhania indeed seems to be closer to the Maastrichtian forms than Accordiella. For the moment being the name of the validly described taxon Accordiella? tarburensis is maintained. Last but not least, some axial sections of Gyroconulina columellifera Schroeder \& Darmoian (see also below) show similarities (Fig. 3d). The marginal part of the chambers in the latter however displays subdivisions (exoskeleton).

Antalyna korayi Farinacci \& Köylüoğlu, 1985 Fig. 3o-t

*1985 Antalyna korayi n. gen., n. sp. - Farinacci and Köylüoğlu, p. 106, pl. 1-2 (upper Maastrichtian of SW Turkey).

2018 Antalyna korayi Farinacci \& Köylüoğlu - Luger, p. 57, pl. 2F, fig. 10, non 8-9 (= Gen. et sp. indet.) (Maastrichtian Auradu Fm. of Somalia).

Remarks: This species has been described by Farinacci and Köylüoğlu (1985) from the upper Maastrichtian of SW Turkey. The type-locality belongs to the Bey Dağlari
Autochthon, part of the Western Taurides (see Sar1 et al., 2009). Farinacci and Köylüoğlu (1985) assigned Antalyna to the family Nezzazatidae Hamaoui \& SaintMarc (agglutinating wall) and notwithstandingly to the superfamily Miliolacea Ehrenberg (porcellaneous wall). A. korayi is not rather frequent in the Iranian Tarbur Formation (Fig. 3p-t). It has a low trochospirally coiled test with angular periphery, and a shallow delicate subepidermal meshwork (with "partitions" of equal length).

\section{Broeckinella arabica Henson, 1948 not figured}

*1948 Broeckinella arabica $\mathrm{n}$. gen., n. sp. - Henson, p. 93, pl. 7, fig. 6, text-fig. 13a-c (Maastrichtian Simsima Fm. of Qatar).

1978 Broeckinella arabica Henson - Cherchi and Schroeder, p. 514, fig. 1 A-C (Maastrichtian Simsima Fm. of Qatar).

1986 Dictyoconella complanata Henson - Köylüoğlu, pl. 96, fig. 1 (Maastrichtian Garzan Fm. of Turkey).

?1997 Dictyoconella complanata Henson - Çoruh et al., pl. 76, fig. 6 (Maastrichtian Garzan Fm. of Turkey).

2004 Dicyclina schlumbergeri - Khosrow Tehrani and Afghah, pl. 2, fig. 4 (upper Maastrichtian Tarbur Fm. of Iran).

2008 Dicyclina schlumbergeri - Khosrow Tehrani et al., pl. 1, fig. 6 (upper Maastrichtian Tarbur Fm. of Iran).

2016 Broeckinella arabica Henson - Schlagintweit and Rashidi, p. 57, fig. 9a-e (upper Maastrichtian Tarbur Fm. of Iran).

2018 Broeckinella arabica Henson - Rashidi and Schlagintweit, fig. 3j (upper Maastrichtian Tarbur Fm. of Iran).

2020 Broeckinella arabica Henson - Schlagintweit and Rashidi, p. 60, figs. 4, 5b-d, 6 (upper Maastrichtian Tarbur Fm. of Iran). 


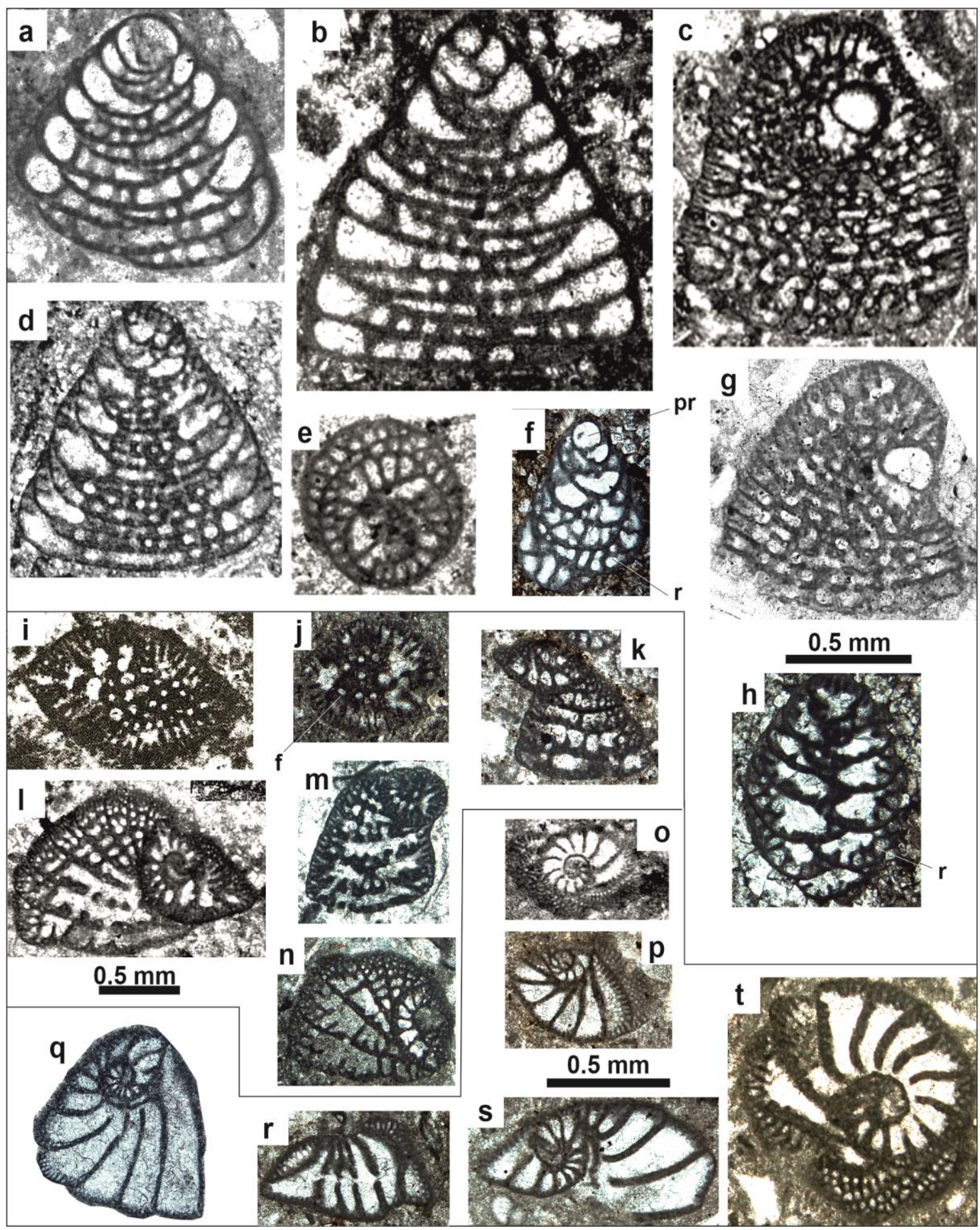

Fig. 3 Larger benthic foraminifera from the Maastrichtian of Iran (Tarbur Fm.: a, d, f-h, j-k, m-n, p-t), Somalia (Auradu Formation: b-c, e, l, o), and Turkey (Garzan Fm.: i). a-b Accordiella? tarburensis Schlagintweit \& Rashidi (a from Schlagintweit and Rashidi, 2016, fig. 6a, holotype, Mandegan section; b from Luger, 2018, pl. 13, fig. 6 as Dukhania? cherchii, holotype). c, g Dictyoconus bakhtiari Schlagintweit, Rashidi \& Babadipour (c from Schlagintweit et al., 2016b, fig. 10b, Naghan section; g from Luger (2018, pl. 6, fig. 4 as Dictyoconus sp. 1). d, e-f, h Gyroconulina columellifera Schroeder \& Darmoian (e from Luger, 2018, pl. 7, fig. 3; d from Schlagintweit et al., 2016a, fig. 4k, Mandegan section; f, h Naghan section). i-n Gen. et sp. indet. (i from Çoruh et al., 1997, pl. 76, fig. 5 as Dictyoconella complanata; $\mathbf{l}$ from Luger, 2018, pl. F-2, fig. 9 as Antalyna korayi; j-k, m-n Naghan section). o-t Antalyna korayi Farinacci \& Köylüoğlu (o from Luger, 2018, pl. F-2, fig. 10; p-t Naghan section). 

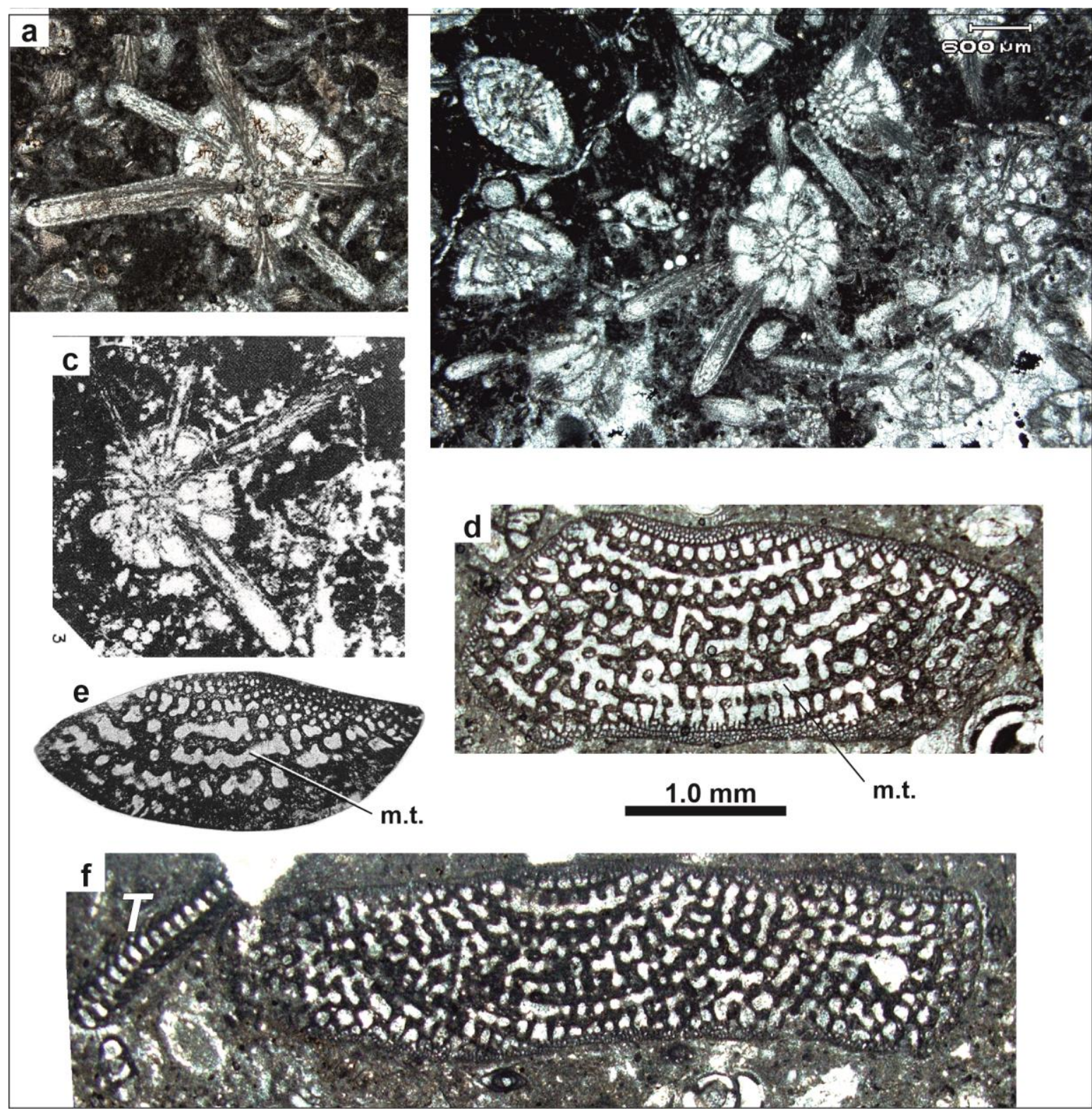

Fig. 4 Larger benthic foraminifera from the Maastrichtian of Iran (Tarbur Fm.: a-b, d, f), Turkey (Garzan Fm.: c), Qatar (Simsima Formation: e). a-c Canalispina iapygia Robles-Salcedo et al. (a-b, Fasa section; c from Çoruh et al., 1997, pl. 76, fig. 3 as Siderolites calcitrapoides). d-f Dictyoconella complanata Henson (d, f Naghan section, e from Henson, 1948, pl. 10, fig. 14). $T=$ Tarburina zagrosiana Schlagintweit $\&$ Rashidi in f. m.t. $=$ marginal trough in $\mathbf{e}$ and $\mathbf{d}$.

Remarks: Besides the known occurrences in the Maastrichtian Simsima Formation of Qatar (Henson, 1948), and Tarbur Formation of Iran (Schlagintweit and Rashidi, 2020), B. arabica is also known from the Garzan Formation SE Turkey figured as Dictyoconella complanata (see synonymy).

Canalispina iapygia Robles-Salcedo, Vicedo, Parente \& Caus, 2019

Fig. $4 \mathrm{a}-\mathrm{c}$

1988 Siderolites calcitrapoides Lamark - Sartorio and Venturini, pag. 129 (Maastrichtian of Sicily and Yemen). 1988 Siderolites denticulatus (Douvillé) - Meriç, pl. 1, figs. $1-8$

1994 Siderolites calcitrapoides Lamarck - Parente, pl. 1, fig. 6 (upper Maastrichtian of southern Italy).
1997 Siderolites calcitrapoides Lamarck - Parente, pl. 26, fig. 4 (upper Maastrichtian of southern Italy).

1997 Siderolites calcitrapoides Lamarck - Çoruh et al., pl. 74, fig. 1 (Maastrichtian Besni Fm. of SE Turkey), pl. 76, fig. 3 (Maastrichtian Garzan Fm. of SE Turkey). 2002 Siderolites calcitrapoides Lamarck - Abramovich et al., pl. 3, figs. 4-6 (upper Maastrichtian of Madagascar).

2003 Siderolites calcitrapoides Lamarck - Abdelghany, figs. 10.13-10.14 (Maastrichtian Simsima Fm. of Oman). 2004 Siderolites calcitrapoides Lamarck - ZambetakisLekkas and Kemeridou, fig. 3c (Maastrichtian of EGreece).

2008 Siderolites calcitrapoides Lamarck - Al-Kubaysi, lower figure page 18 (Maastrichtian Aqra Fm. Iraq).

2017 Siderolites denticulatus - Solak et al., fig. 12v (Maastrichtian of S-Turkey, western Central Taurides). 
2019 Siderolites calcitrapoides Lamarck - Abdallah and Al-Dulaimi, pl. 1, fig. 1 (Maastrichtian Aqra Fm. of Iraq). *2019 Canalispina iapygia Robles-Salcedo et al. - Robles-Salcedo et al., figs. 4, 6-7 (upper Maastrichtian of southern Italy).

2019 Canalispina iapygia Robles-Salcedo et al. - Septfontaine et al., fig. 5 (upper Maastrichtian Tarbur Fm. of Iran).

2019 Canalispina iapygia Robles-Salcedo et al. Consorti et al., fig. 5 (upper Maastrichtian Tarbur Fm. of Iran).

Remarks: According to Robles-Salcedo et al. (2019), C. iapygia represents an upper Maastrichtian marker taxon. It has been reported from the Garzan Fm. of SE Turkey as Siderolites calcitrapoides Lamarck (Çoruh et al., 1997). Main differences between Siderolites Lamarck and Canalispina refer to the microstructure of the spines (Robles-Salcedo et al., 2019; Consorti et al., 2019). In the Tarbur Formation, both taxa are present.

\section{Cyclopsinella steinmanni (Munier-Chalmas, 1887)}

Fig. 5

1963 Cyclopsinella steinmanni (Munier-Chalmas) Gendrot, p. 531, pl. 1, figs. 6-10, text-figs. 1-2.

1971 Cyclopsinella steinmanni (Munier-Chalmas) - Ramírez del Pozo, pl. 116, pars (upper Santonian of northern Spain).

1974b Cyclopsinella steinmanni (Munier-Chalmas) Meriç, pl. 1, figs. 1-3 (Maastrichtian of SE Turkey).

?2019 Cyclopsinella roselli n. sp. - Villalonga et al., p. 10, fig. 10a-e (middle Campanian Terradets Limestone of NE Spain).

2018 Saudia sp. - Luger, p. 61, pl. 4, fig. 10 (Maastrichtian Auradu Fm. of Somalia)..

Remarks: This taxon, which sometimes attains an irregular-discoidal morphology in axial sections, seems to be extremely rare in the Auradu Formation of Somalia (Fig. 5a). Luger (2018, p. 61) did neither provide any description nor dimensional data. Measured from the illustration, the shown axial section is $\sim 4 \mathrm{~mm}$ in diameter, $\sim 0.35 \mathrm{~mm}$ in thickness, and consists of more than 45 annular chambers. The chamber height is continuously increasing throughout ontogeny resulting in biconcave disk-like outline in axial sections. The low magnification and poor quality of the image, however, do not allow further insights into other details such as the initial chambers. In the adult chambers, aligned central pillars (cyclopsellinid endoskeleton sensu Hottinger, 2006, p. 12) are well recognizable. This feature, and the lack of an endoskeleton in the early part of the test, is also displayed in the specimen from the Tarbur Formation shown in Figure 5b. In another specimen from the Tarbur Formation, a sporadic single, very short (= rudimentary) rafter in the marginal chamber part can be observed (Fig. 5e). This feature has never been observed in older (Cenomanian-Campanian) species. It is here considered as an intraspecific variation like reported from some orbitolinids (e.g., Simplorbitolina manasi Ciry \& Rat; see Schroeder, 1985). The specimens from Somalia and Iran are well comparable to the upper Santonian forms of southern France (Gendrot,
1964) (Fig. 5d). From SE Turkey, C. steinmanni has been reported by Meriç (1974) from the Maastrichtian of oil drilling wells Şelmo-1 and Malabadi-1, Siirt Province. No lithostratigraphic unit has been indicated by Meriç, but it should correspond to the so-called Koçali Complex, a lithostratigraphic equivalent of the Garzan Formation (Hoşgör and Košt'ák, 2012, fig. 2).

Another species of the genus Cyclopsinella has recently been described by Villalonga et al. (2019) as C. roselli from the middle Campanian of NE Spain. However, some important taxonomic works on Cyclopsinella by Gendrot (1963), Neumann (1964), Meriç (1974b), and Cherchi $(1980,1985)$ have not been taken into consideration by Villalonga et al. (2019). Otherwise, a pure comparison and analysis of the therein provided data with respect to test diameter and number of chambers should have made very doubtful its creation (Table 2). In this context, the overlapping stratigraphy, upper Santonian-Maastrichtian for C. steinmanni (see synonymy), and middle Campanian for $C$. roselli, is also worth mentioning. By the way, the specimens of $C$. roselli show an almost complete fusion of the pillars in the interior of the last chambers. The typical tendency of this particular pattern (Hottinger, 2006, p.12) has not been mentioned in the description of C. roselli.

Zekritia (type-species Z. langhami) described by Henson (1948) from the Cenomanian of Qatar might be a junior synonym of Cyclopsinella (see Gendrot, 1964; Fourcade et al., 1994). Z. langhami would then be a junior synonym of the Cenomanian $C$. neumannae Cherchi (see Cherchi, 1980, 1985). In fact, the single section shown by Henson (1948, pl. 11, fig. 7) displays the typical cyclopsinellid structure of the pillars (Hottinger, 2006, p. 12). Loeblich and Tappan (1987, p. 715) treat Zekritia as a genus of uncertain status.

\section{Dictyoconella complanata Henson, 1948}

Fig. 5d-f

*1948 Dictyoconella complanata n. gen., n. sp. - Henson, p. 25, pl. 6, figs. 2-3, 16, pl. 10, fig. 14 (Maastrichtian Simsima Fm. of Qatar).

2004 Dicyclina schlumbergeri, Dictyconella sp. Khosrow Tehrani and Afghah, pl. 2, figs. 4, 10 (Maastrichtian Tarbur Fm. of Iran).

? 2014 Antalyna korayi Farinacci \& Köylüoğlu - Afghah and Yaghmour,pl. 2, fig. 5 (Maastrichtian Tarbur Fm. of Iran).

Remarks: In his important monograph on MesozoicCenozoic Larger Benthic Foraminifera from the area of the Middle East-South-Western Asia, Henson (1948) erected the genus Dictyconella for more or less "compressed-conical" dictyoconids including the two species D. complanata and D. minima. Both are however structurally completely different and cannot be assigned to the same genus (see Schlagintweit et al., 2016b). A revision is currently under preparation. The type-species D. complanata was described from Maastrichtian carbonates of the Simsima Formation of Dukhan No. 1 well of Qatar. Henson (1948, p. 24-25) noted the presence of a "zone with undivided chamber space" (or marginal ridge) between the marginal (with exoskeleton) and central zones 
Table 2 Comparison of biometric and stratigraphic data of Cyclopsinella steinmanni (Munier Chalmas) and its assumed junior synonym Cyclopsinella roselli Villalonga et al.

\begin{tabular}{|c|c|c|c|}
\hline species & \multicolumn{2}{|c|}{ Cyclopsinella steinmanni (Munier Chalmas, 1887) } & \multirow{2}{*}{$\begin{array}{l}\text { Cyclopsinella roselli Villalonga } \\
\text { et al., } 2019\end{array}$} \\
\hline reference & $\begin{array}{l}\text { acc. to Gendrot, } 1964 \\
* \\
\text { Cherchi, } 1980 * *\end{array}$ & $\begin{array}{l}\text { acc. to Villalonga et al., } \\
2019\end{array}$ & \\
\hline Test diameter & $\begin{array}{l}\text { up to } 10 \mathrm{~mm} * \\
6-7 \mathrm{~mm} * *\end{array}$ & $\begin{array}{lcc}\text { average } & 4.4 & \mathrm{~mm} \\
\text { (maximum } & 5.1 \mathrm{~mm} \text { ) } & \\
\end{array}$ & $\begin{array}{lccc}\begin{array}{l}\text { average } \\
\text { (maximum } 9.1 \mathrm{~mm})\end{array} & 8.0 & \mathrm{~mm} \\
\end{array}$ \\
\hline $\begin{array}{l}\begin{array}{l}\text { Number } \\
\text { chambers }\end{array} \\
\end{array}$ & up to $50 *$ & Average 42 & may be over 50 (average 48 ) \\
\hline $\begin{array}{l}\text { Number of initial } \\
\text { chambers } \\
\text { without } \\
\text { endoskeleton }\end{array}$ & & $9-12$ & $14-17$ \\
\hline Stratigraphy & \multicolumn{2}{|c|}{ Upper Santonian-Maastrichtian } & Middle Campanian \\
\hline Occurrences & \multicolumn{2}{|c|}{ S-France, N-Spain, Somalia, SE Turkey, SW Iran } & NE-Spain \\
\hline
\end{tabular}

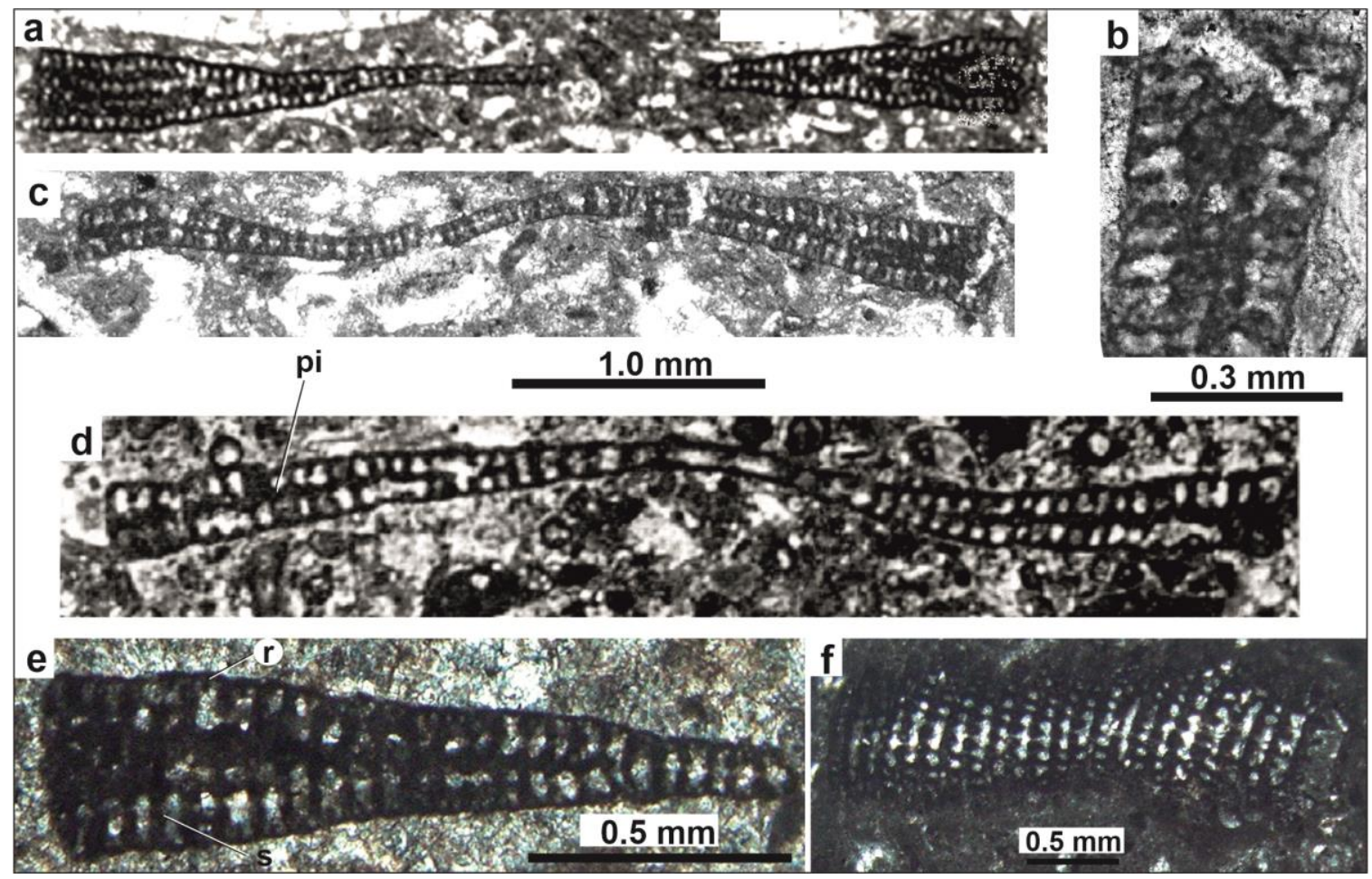

Fig. 5 Cyclopsinella steinmanni (Munier-Chalmas) from the upper Maastrichtian of Somalia (Auradu Formation: a), Iran (Tarbur Formation: b-c, e-f), and C. steinmanni from the upper Santonian of France (d). a from Luger (2018, pl. 4, fig. 10 as Saudia sp.). b-c, e-f Naghan section. Note the aligned pillars (partly fusing laterally) in $\mathbf{b}$ and $\mathbf{f}$, and sporadic rudimentary short rafter (r) in e. $\mathbf{d}$ from Gendrot (1964, pl. 1, fig. 10). Abbreviations: pi = pillar, $r=$ rafter, $s=$ septum.

(with endoskeleton; see also Hottinger, 2006, p. 22) as described also from Dictyoconus Blanckenhorn by Davies (1938: marginal trough, see Fig. 4d-e). There is reference that indicate the presence of $D$. complanata in the Garzan Formation of SE Turkey (Çoruh et al., 1997), but real evidence is lacking so far.

Dictyoconus bakhtiari Schlagintweit, Rashidi \& Babadipour 2016

Fig. 3c, g

1948 Dictyoconus cf. arietinus Silvestri - Henson, p. 34, pl. 7, fig. 1, text-fig. 3 (Maastrichtian of Qatar; Dukhan no. 1 well).

*2016b Dictyoconus bakhtiari n. sp. - Schlagintweit et 76 al., p. 34, figs. 3c-d pars, 7-10 (late Maastrichtian Tarbur Formation, Iran).

2018 Dictyoconus sp. 1 - Luger, p. 69, pl. 6, figs. 3-4, 6 (late Maastrichtian Auradu Formation, Somalia).

Remarks: In the paper about late Maastrichtian orbitolinids of Schlagintweit et al. (2016b), a table with the dimensions of Dictyoconus bakhtiari has been forgotten. It is included here supplementing the original description (Table 3). For Dictyoconus sp. 1 (= Dictyoconus bakhtiari Schlagintweit, Rashidi \& Babadipour), Luger (2018) observed only megalospheric specimens, with proloculi diameters up to $0.21 \mathrm{~mm}$ (Schlagintweit et al. 2016b: up to $0.2 \mathrm{~mm}$ ), and test height up to $2.34 \mathrm{~mm}$ (up to $2.5 \mathrm{~mm}$ ). According to Luger (2018), Dictyoconus sp. 
Table 3 Biometric data of Dictyoconus bakhtiari from the upper Maastrichtian Tarbur Formation of SW Iran (see Schlagintweit et al., 2016b).

\begin{tabular}{|c|c|c|c|c|c|c|}
\hline test diameter $(d)$ & test height (h) & $\mathbf{d} / \mathbf{h}$ & $\begin{array}{l}\text { diameter } \\
\text { protoconch }\end{array}$ & $\begin{array}{l}\text { diameter } \\
\text { deuteroconch }\end{array}$ & $\begin{array}{l}\text { Number of } \\
\text { chambers last } \\
\text { mm }\end{array}$ & $\begin{array}{l}\text { Thin- } \\
\text { section }\end{array}$ \\
\hline 2.0 & 2.0 & 1.0 & - & - & 10 & 2NG 53 \\
\hline- & - & - & 0.17 & - & - & NG 53-1 \\
\hline 1.9 & 2.4 & 0.8 & - & - & 8 & NG 52-2 \\
\hline 1.7 & 2.5 & 0.7 & - & - & 9 & NG 53-2 \\
\hline 2.0 & 2.2 & 0.9 & - & - & 10 & NG 64 \\
\hline 4.8 (B-form) & - & - & - & - & - & $2 \mathrm{NG} 81$ \\
\hline 4.5 (B-form) & - & - & - & - & - & NG 87-2 \\
\hline 3.6 (B-form) & - & - & - & - & - & $2 \mathrm{NG} 87-2$ \\
\hline 4.15 (B-form) & 3.2 & 1.3 & - & - & - & $2 \mathrm{NG} 83$ \\
\hline 1.7 & 2.1 & 0.81 & 0.2 & 0.16 & 9 & 2NG 87-2 \\
\hline 1.2 & 0.83 & 1.45 & 0.17 & 0.12 & - & 2NG $87-3$ \\
\hline 1.85 & 2.4 & 0.8 & - & 0.2 & 10 & Rt 62-1 \\
\hline 2.0 & 2.2 & 0.9 & - & - & 9 & NG 54 \\
\hline 1.85 & 2.1 & 0.9 & 0.15 & 0.2 & 10 & $2 \mathrm{NG} 32$ \\
\hline 1.55 & 1.8 & 0.86 & - & - & 10 & $2 \mathrm{NG} 16$ \\
\hline 1.62 & 1.92 & 0.84 & - & - & 10 & $2 \mathrm{NG} 16$ \\
\hline 1.45 & 2.2 & 0.65 & 0.17 & - & 10 & 2NG 27 \\
\hline 2.0 & 2.4 & 0.85 & - & - & 9 & $2 \mathrm{NG} 53$ \\
\hline 2.4 & 2.3 & 1.05 & - & - & 9 & NG 83-3 \\
\hline 1.6 & 1.45 & 1.1 & 0.19 & 0.165 & - & 2NG 112 \\
\hline $\begin{array}{l}1.15 \\
\text { form) }\end{array}$ & 1.0 & 1.15 & 0.2 & 0.23 & - & $2 \mathrm{NG} 69$ \\
\hline $\begin{array}{l}\text { Ranges A forms: } \\
1.2-2.4\end{array}$ & $0.83-2.5$ & $\begin{array}{l}0.65- \\
1.45\end{array}$ & $0.15-0.2$ & $0.12-0.23$ & $8-10$ & \\
\hline $\begin{array}{l}\text { Ranges B forms: } \\
3.6-4.8\end{array}$ & 3.2 (one value) & $\begin{array}{l}1.3 \\
\text { (one } \\
\text { value) }\end{array}$ & - & - & - & \\
\hline
\end{tabular}

1 (Fig. 3c) is rather frequent in the lower (= upper Maastrichtian) part of the Auradu Formation.

\section{Gen et. sp. indet}

Fig. 3i-n

1997 Dictyoconella complanata Henson - Çoruh et al., pl. 76, fig. 5 (late? Maastrichtian Garzan Formation).

2004 Antalyna korayi Farinacci \& Köylüoğlu - Khosrow Tehrani and Afghah, pl. 1, fig. 11 (late? Maastrichtian Tarbur Formation of Iran).

2008 Antalyna korayi Farinacci \& Köylüoğlu - Khosrow Tehrani et al, pl. 1, fig. 1 (late? Maastrichtian Tarbur Formation of Iran).

2009 Antalyna korayi Farinacci \& Köylüoğlu - Afghah, pl. 1, fig. 1 (late? Maastrichtian Tarbur Formation of Iran).

2009 Dictyoconella sp. - Afghah, pl. 1, fig. 3 (late? Maastrichtian Tarbur Formation of Iran).

2018 Antalyna korayi Farinacci \& Köylüoğlu - Luger, pl. 2, figs. 8-9 (late? Maastrichtian Auradu Formation of Somalia).

2018 Dicyclina sp. - Payandeh et al., pl. 6, fig. 3, Maastrichtian Tarbur Fm. of Iran).

Remarks: This species has been reported several times from the Maastrichtian Tarbur Formation of Iran assigned either to Dictyoconella Henson, Dicyclina Schlumberger, or Antalyna Farinacci \& Köylüoğlu (see synonymy). It is currently under detailed study, believed to be different to these genera. Apart from the Iranian Tarbur Formation, it is also reported from the Turkish Garzan Formation (Çoruh et al., 1997). From the upper Maastrichtian Auradu Formation of Somalia it was reported as A. korayi (Luger, 2018, pl. 2, figs. 8-9).

Gyroconulina columellifera Schroeder \& Darmoian, 1977

Fig. 3d-f, h

1977 Gyroconulina columellifera n. gen., n. sp. Schroeder \& Darmoian, p. 120, pl. 1, figs. 1-4, pl. 2, figs. 1-7, text-fig. 2 (Maastrichtian Aqra Formation of Iraq).

1985 Gyroconulina columellifera Schroeder \& Darmoian - Al-Rawi and Al-Hamadani, pl. 4, fig. 3 (?), 4.

1986 Gyroconulina columellifera Schroeder \& Darmoian - Farinacci and Yeniay, p. 260, not figured.

1986 Gyroconulina aqraensis n. sp. - Lawa et al., p. 77, pl. 1, figs. 3-6, pl. 2, figs. 7-8, pl. 4, figs. 16-17.

1986 Gyroconulina columellifera Schroeder \& Darmoian - Lawa et al., pl. 1, figs. 1-2, pl. 2, figs. 9-10, pl. 3, figs. 11-13, pl. 4, figs. 14-15. 
1995 Gyroconulina columellifera Schroeder \& Darmoian - Whittaker et al., pl. 11, figs. 1-2, pl. 58, figs. 1-5 (Maastrichtian of Iraq, and Saudi Arabia).

?1997 Coskinolina sp. - Çoruh et al., pl. 75, fig. 3 (Maastrichtian Garzan Formation of Turkey).

?2014 Coskinolina sp. Afghah and Yaghmour, pl. 2, fig. 2 (Maastrichtian Tarbur Formation, Iran).

2016a Gyroconulina columellifera Schroeder \& Darmoian - Schlagintweit et al., p. 172, figs. 3-5, 6B pars (late Maastrichtian Tarbur Formation, Iran).

2018 Gyroconulina columellifera Schroeder \& Darmoian - Luger, p. 68, pl. 7, figs. 1-3 (late Maastrichtian Auradu Formation of Somalia).

2018 Dukhania? cherchii n. sp. - Luger, p. 68, pl. 13, fig. 9 (late Maastrichtian Auradu Formation of Somalia).

Remarks: For detailed descriptions see Schroeder \& Darmoian (1977) and Schlagintweit et al. (2016a).

Palaeoelphidium multiscissuratum (Smout, 1955) Fig. 2 below, pars

*1955 Elphidiella multiscissurata n. sp. - Smout, p. 208, figs. 6-9 (upper Maastrichtian of Qatar, and Iraq).

2018 Laffiteina aff. jaskii Rahaghi - Luger, pl. 26, fig. 10 (upper Maastrichtian Auradu Formation of Somalia).

2018 Palaeoelphidium multiscissuratum (Smout) n. gen., n. comb. - Consorti et al., p. 166, figs. 3-5 (upper Maastrichtian Tarbur Formation of Iran) (cum syn.).

Remarks: The species has been described by Smout (1955) as Elphidiella multiscissurata from Maastrichtian marls of Qatar, associated with Siderolites, Loftusia, and Omphalocyclus. In addition, Smout noted the occurrence in the Aqra Limestone of Iraq within an equivalent assemblage of LBF. For the Tarbur Formation of Iran, Wynd (1965) established an upper Elphidiella multiscissurata subzone within his Omphalocyclus Loftusia assemblage zone. In some recent papers, it has been illustrated as Rotalia skourensis (Pirbaluti et al., 2013, fig. 8.13; Payandeh et al., 2016, pl. 1, fig. 6). This taxon is considered by Consorti et al. (2018) as the oldest Elphidium-like foraminifer known so far.

\section{Pseudedomia hamaouii Rahaghi, 1976}

Fig. 6

1976 Pseudedomia hamaouii n. sp. - Rahaghi, p. 6, pl. 1, fig. 1-11 (Campanian Gurpi Formation of Iran).

1997 Fallotia sp. - Çoruh et al., pl. 74, figs. 4-5 (late? Maastrichtian Besni Formation of Turkey).

2010 Fallotia? sp. (probably new genus) - Sirel, pl. 2, figs. 5-13 (late Maastrichtian Beyobasi Formation of Turkey).

2016a Fallotia jacquoti Douvillé - Schlagintweit et al., fig. 7L (late Maastrichtian Tarbur Formation of Iran).

?2017 Pseudedomia hekimhanensis Görmüş - Solak et al., fig. 12 T1-T3 (Maastrichtian of S-Turkey).

2018 Pseudedomia sp. - Luger, p. 95, pl. 16, fig. 10 (late Maastrichtian Auradu Formation of Somalia).

Remarks: Test diameter is mostly between $1.6 \mathrm{~mm}$ and $2.0 \mathrm{~mm}$ (maximum $2.2 \mathrm{~mm}$ ), thickness is $0.3 \mathrm{~mm}$ to 0.5 78 $\mathrm{mm}$. The tiny proloculus observed in some forms has a diameter from $0.06 \mathrm{~mm}$ to $0.07 \mathrm{~mm}$ (Fig. 6d). Adult specimens consist of up to 15 planispirally-involute coiled whorls. The original material of Rahaghi was deriving from two localities in the Zagros Zone belonging to the so-called Lopha Limestone Member of the Gurpi Formation and assigned to the upper Campanian (Wynd, 1965; Hashmie et al., 2020). P. hamaouii is intermediate in size between the smaller $P$. hekimhanensis from the late Campanian?-Maastrichtian of Turkey (Görmüş, 1999) and the larger type-species $P$. striata from the Maastrichtian of Qatar (Henson, 1948). The specimens from Iran have been observed in the lower part of the Tarbur Formation in bioclastic packstones together with siderolitids, and Omphalocyclus (Fig. 6a). In southern Turkey it is recorded as $P$. hekimhanensis by Solak et al. (2019, fig. 9) from strata assigned to the lower Maastrichtian, namely an "Orbitoides, Omphalocyclus, Siderolites assemblage zone".

\section{Pseudorbitolina schroederi Luger, 2018}

Fig. 7

1948 Pseudorbitolina marthae Douvillé - Henson, p. 102, pl. 6, fig. 17, pl. 11, fig. 6 ?, text-fig. 16 (Maastrichtian Simsima Formation of Qatar, see Sugden and Standring, 1975).

1974b Pseudorbitolina marthae Douvillé - Meriç, pl. 1, figs. 1-4, pl. 2, figs. 1-3 (upper Maastrichtian of SE Turkey).

1979 Pseudorbitolina marthae Douvillé - Radoičić, pl. 8, figs. 1-3 (Maastrichtian of Iraq).

2016b Pseudorbitolina cf. marthae Douvillé Schlagintweit et al., p. 41, Figs. 3e-f, 11 (Maastrichtian of Iran).

2016 Antalyna korayi Farinacci \& Köylüoğlu - Deghani et al., pl. 2, fig. 13 (Maastrichtian Tarbur Fm. of Iran).

non 2016 Pseudorbitolina marthae Douvillé - AlKubaysi and Abid, figs. 6-1 to 6-3 (= Suraqalatia brasieri Görmüş, Lawa \& Al Nuaimy).

2018 Pseudorbitolina schroederi n. sp. - Luger, p. 72, pl. 7, figs. 6-9 (upper Maastrichtian Auradu Formation of Somalia).

Remarks: With its convexo-concave test of annularconcentric chambers more or less throughout the complete ontogeny, Pseudorbitolina represents a rather unusual representative among the orbitolinids. In the drawing of Douvillé (1912, fig. 3), the monospecific genus Pseudorbitolina shows a subspherical proloculus in apical position displaying a septulated supraembryonic zone at its top (like in Palorbitolina, see Schroeder, 1963, fig. 1). The thin-section specimens illustrated by Neumann (1978, pl. 1, fig. 7, pl. 2, fig. 6) in transverse sections instead show an embryo in apical position consisting of a spherical proloculus and a hemispherical septulated deuteroconch arranged laterally to the former. In conclusion, there are still informations lacking on the exact structure of the embryo in Pseudorbitolina (incl. interpretation of elements). In the revision of the species provided by Neumann (1978), the author concludes that it represents a good marker for the Campanian. Schlagintweit et al. (2016b, p. 41) already remarked that obviously there is a 

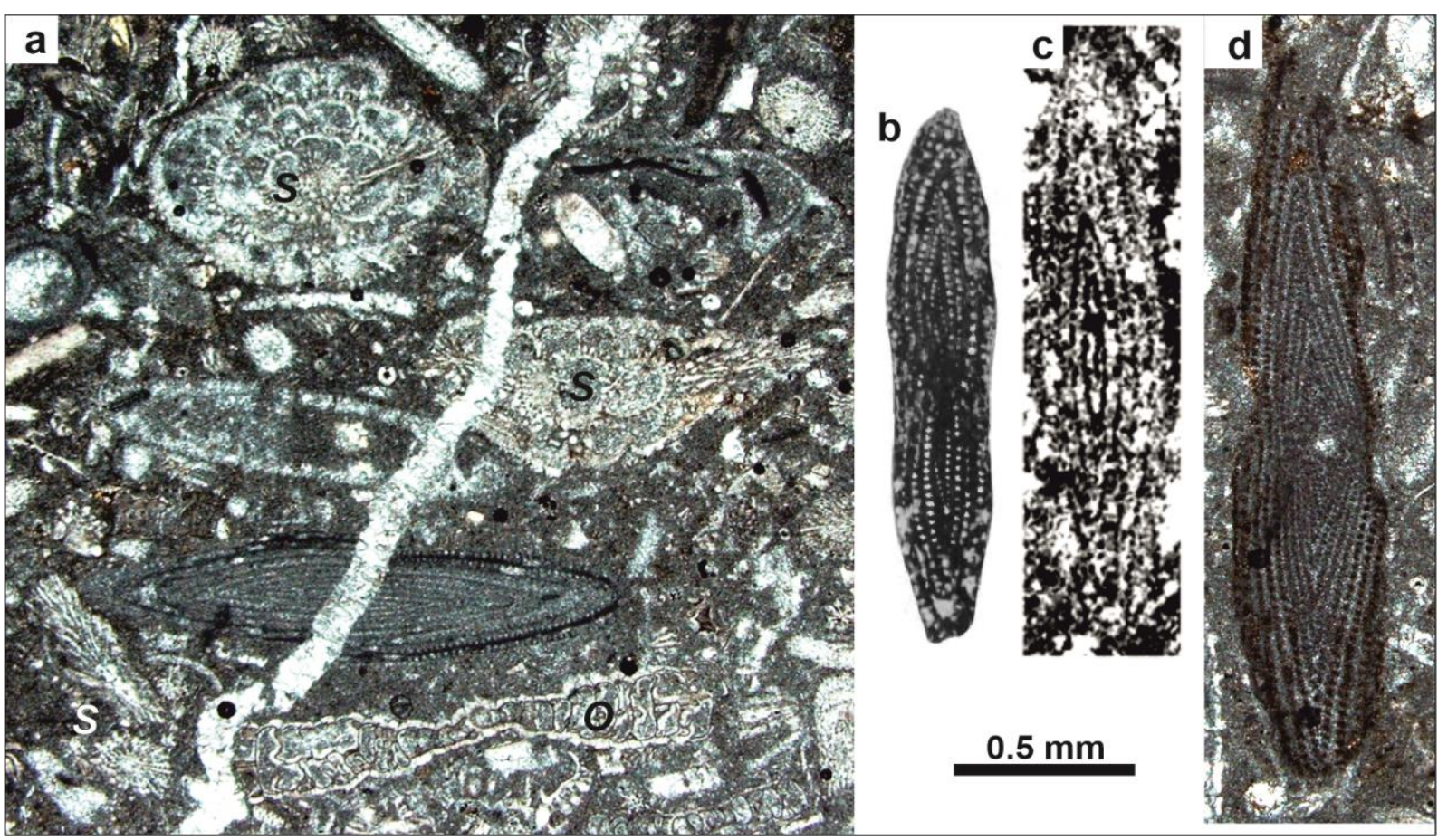

Fig. 6 Pseudedomia hamaouii Rahaghi from the Campanian (Lopha Limestone Member: b), and upper Maastrichtian of Iran (Tarbur Formation: a, d), and Somalia (Auradu Formation: c). a Bioclastic packstone with P. hamaouii Rahaghi, Siderolites calcitrapoides Lamarck (S), and Omphalocyclus macroporus Lamarck (O); Fasa section. b from Rahaghi (1976, pl. 1, fig. 11). c from Luger (2018, pl. 16, fig. 10 as Pseudedomia sp.). d Fasa section.

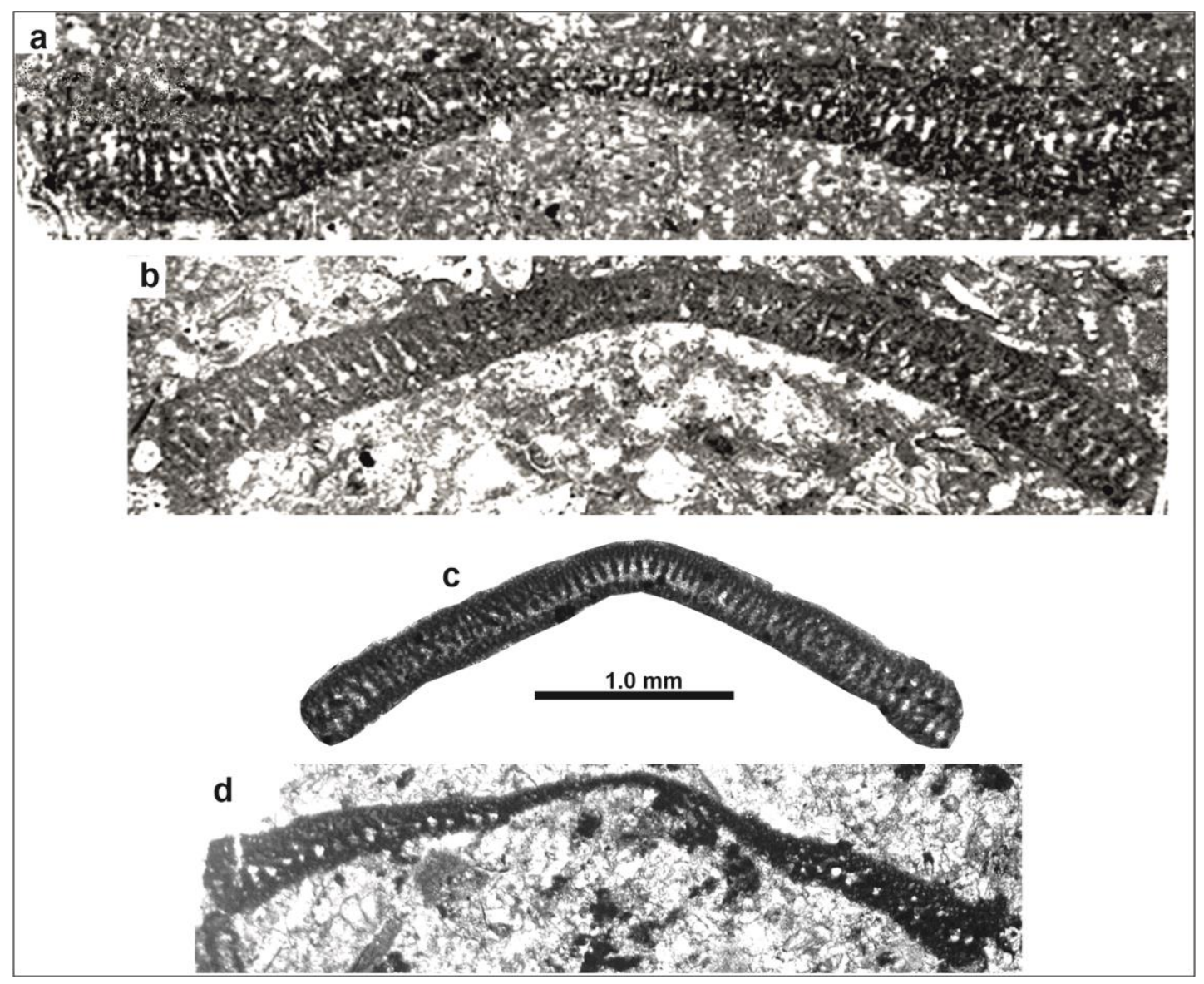

Fig. 7 Pseudorbitolina schroederi Luger from the Maastrichtian of Somalia (Auradu Formation, a-b), and Iran (Tarbur Formation, c-d). a, b from Luger (2018, pl.7, figs. 7-8; holotype in 7), c-d from Naghan section (d from Schlagintweit et al. (2016b, fig. 11c as Pseudorbitolina marthae). 
stratigraphic discrepancy between the occurrences in Western Europe and the Middle East area (incl. also the record from Somalia; see synonymy). Both, Meriç (1974) and Schlagintweit et al. (2016b) also remarked the greater test dimensions of the Middle East specimens.

Luger (2018, p. 72) described Pseudorbitolina schroederi as possessing the same internal structure like the typespecies $P$. marthae. The test size (diameter) of the Campanian $P$. marthae is 2-3 mm (Douvillé, 1910; Neumann, 1978). For the Maastrichtian P. schroederi Luger (2018) indicated a maximum diameter of $6.08 \mathrm{~mm}$. The separation of two Pseudorbitolina species based on size, different stratigraphy, and apparently different palaeobiogeographic distribution is accepted here. Note that in the Maastrichtian deposits of SE Turkey, P. marthae is restricted to the southeastern part belonging to the Arabian platform (Meriç, 1974a; Özer et al., 2009).

\section{ACKNOWLEDGEMENTS}

Thanks to Koorosh Rashidi (Yazd) for providing the material from Tarbur Formation; Ercan Özcan (Istanbul) and Cemile Solak (Mersin) for help with the acquisition of literature from Turkey. The reviewers Cemile Solak (Mersin), Mohsen Yazdi-Moghadam (Tehran), and Lorenzo Consorti (Trieste) are thanked for helpful comments.

\section{REFERENCES}

Abdelghany, O., 2003. Late Campanian-Maastrichtian foraminifera from the Simsima Formation on the western side of the Northern Oman Mountains. Cretaceous Research, 24: 391-405.

Abdallah, F.T., Al-Dulaimi, S.I., 2019. Biostratigraphy of the Upper Cretaceous for selected sections in northern Iraq. Iraqi Journal of Science, 60 (3): 545-553.

Abramovich, S., Keller, G., Adatte, T., Stinnesbeck, W., Hottinger, L., Stueben, D., Berner, Z., Ramanivosoa, B., Randriamanantenasoa, A., 2002. Age and paleoenvironment of the Maastrichtian and Paleocene of the Mahajanga Basin, Madagascar: a multidisciplinary approach. Marine Micropalaeontology, 47: 1770 .

Afghah, M., 2009. New investigations of the Tarbur Formation lithostratigraphy in the review of type section and its correlation with Kuh-e Tir section. Journal of Sciences Islamic Azad University, 19 (73): 183196.

Afghah, M., Yaghmour, S., 2014. Biostratigraphy study of Tarbur Formation (Upper Cretaceous) in TangE Kushk and east of Sarvestan (SW of Iran). Journal of Earth Science, 25 (2): 263-274.

Ala, M.A., Moss, B.J., 1979. Comparative petroleum geology of southeast Turkey and northeast Syria. Journal of Petroleum Geology, 1 (4): 3-27.

Ali, M.Y., 2006. Petroleum geology and hydrocarbon potential of Somaliland. First break, 24, 49-54.

Ali, M.Y., 2015. Petroleum geology and hydrocarbon potential of the Guban Basin, northern Somaliland. Journal of Petroleum Geology, 38 (4): 433-458.

Al-Dulaimi, S.I., Al-Obaidy, R.A., 2017. Biostratigraphy of Bekhme Formation (Upper Cretaceous) in select- ed sections, Kurdistan region, northeast Iraq. Iraqi Bulletin of Geology and Mining, 13 (1): 1-14.

Al-Kubaysi, K.N., 2008. Biostratigraphy of Aqra, Tanjero and Shiranish Formations in Chwarta, Area, Sulaimaniyah governorate, NE Iraq. Geology and Mine of Iraq, 4 (2): 1-23.

Al-Kubaysi, K.N., Abid, A.A., 2016. A new record of foraminifera species (Pseudorbitolina marthae Douville) indicating the late maastrichtian stage within the Aqra Formation in Chwarta area, Sulaimaniyah governorate, ne Iraq. Journal of Zankoy Sulaimani Special Issue, Geo Kurdistan II: 203-212.

Al-Rawi, D., Al-Hamadani, T.A., 1985. Microfacies study of Aqra Limestone in the type section and Geli Zinta section and reconstruction of the paleoclimate. Journal Geological Society of Iraq, 18 (1): 115-161.

Barrier, E., Vrielynck, B., 2008. Palaeotectonic maps of the Middle East: Tectono-sedimentary-palinspastic maps from the Late Norian to Pliocene. Commission for the Geological Map of the World (CGMW / CCGM), Paris, 14 maps.

Carbone, F., Matteucci, R., Pignatti, J.S., and Russo, A., 1993. Facies analysis and biostratigraphy of the Auradu Limestone Formation in the Berbera-Sheikh area, northwestern Somalia. Geologica Romana, 29: 213-235.

Cherchi, A., 1980. Cyclopsinella neumannae n. sp. (Lituolidae, Foram.) dell Cenomaniano medio della Francia sud-occidentale. Revista Española de Micropaleontología, 12(1): 71-86.

Cherchi, A., 1985. Genre Cyclopsinella Galloway, 1933. In: Schroeder, R., Neumann, M. (coords.) Les Grands Foraminifères du Crétacé Moyen de la région Méditerranénne. Géobios Mémoire Spécial, 7: 19-21.

Cherchi, A., Schroeder, R., 1978. Revision of the type of Broeckinella arabica Henson (Foram.) from Qatar Peninsula (Arabia). Neues Jahrbuch für Geologie und Paläontologie Monatshefte, 9: 513-520.

Cherchi, A., Fantozzi, P.L., Abdirahman, H., 1993. Micropaleontological data on the Jurassic-

Cretaceous sequences and the Cretaceous-Paleocene boundary in Northern Somalia (Bosaso region). C.R. Acad. Sci. Paris, t. 316, Sér. II: 1179-1185.

Consorti, L., Köroğlu, F., 2019. Maastrichtian-Paleocene larger Foraminifera biostratigraphy and facies of the Şahinkaya Member (NE Sakarya Zone, Turkey): Insights into the Eastern Pontides arc sedimentary cover. Journal of Asian Earth Sciences, 183: 103965.

Consorti, L., Schlagintweit, F., Rashidi, K., 2018. Palaeoelphidium gen. nov. (type species: Elphidiella multiscissurata Smout 1955): The oldest Elphidiellidae (benthic foraminifera) from Maastrichtian shallowwater carbonates of the Middle East. Cretaceous Research, 86: 163-169

Consorti, L., Schlagintweit, F., Rashidi, K., 2019. A new Idalina (Milioloidea, benthicForaminifera) from the upper Maastrichtian Tarbur Formation of SW Iran and some associated fauna. Historical Biology. https://doi.org/10.1080/08912963.2109.1663842.

Çoruh, T., Yakar, H., Ediger, V.Ş., 1997. Güneydoğu Anadolu Bölgesi Otokton Istifinin Biyostratigrafi Atlasi. Türkiye Petrolleri Anonim Ortaklığı, Araştırma 
Merkezi Grubu Başkanliği Eğitim Yayinlari, 30: 510 p.

Cox, P., 1937. The genus Loftusia in south western Iran. Eclogae Geologicae Helvetiae, 30: 431-450.

Davidson, L.M., Arthur, T.J., Smith, G.F., Tubb, S., 2018. Geology and hydrocarbon potential of offshore SE Somalia. Petroleum Geoscience, 24: 247-257.

Davies, L.M., 1939. An early Dictyoconus, and the genus Orbitolina: their contemporaneity, structural distinction, and respective natural allies. Transactions of the Royal Society of Edinburgh, 59: 773-790.

Deghani, M., Vaziri, S.H., Ahmadi, V., 2016. Lithostratigraphy and microbiostratigraphy of The Tarbur Formation in the Zangeneh section of interior Fars (Folded Zagros), South of Iran. International Journal of Humanities and Cultural Studies, 2 (4): 1873-1884.

Douvillé, H., 1910. La Craie et le Tertiaire des environs de Royan. Bulletin de la Société géologique de France, (4) sér., 10 (1/2): 51-61.

Drobne, K., Hottinger, L., 1971. Broeckinella und Saudia (Foraminiferida) aus dem nordwestlichen Teil Jugoslawiens. Razprave Dissertationes, 14: 215-238.

Dubicka, Z., Peryt, D., 2012. The Lower/Upper Maastrichtian boundary interval in the Lublin Syncline (SE Poland, Boreal realm): new insight into foraminiferal stratigraphy. Newsletters on Stratigraphy, 45 (2), 139-150.

Farinacci, A., Köylüoğlu, M., 1985. Antalyna korayi n. sp. in the phyletic lineage of the Nezzazatidae (Foraminifera). Revue de Micropaléontologie, 28 (2): 103-108.

Farinacci, A., Yeniay, G., 1986. Biostratigraphy and event-analysis of the Cenomanian-Maastrichtian carbonates of the Bey Daglari (Western Taurus, Turkey). Geologia Romana, 25: 257-284.

Farouk, S., 2014. Maastrichtian carbon cycle changes and planktonic foraminiferal bioevents at Gebel Matulla, west-central Sinai, Egypt. Cretaceous Research, 50: 238-251.

Fourcade, E., Mouty, M., Teherani, K.K., 1997. Levantinella nov. gen. et révision du genre Mangashtia Henson, grands Foraminifères du Jurassique et du Crétacé du Moyen-Orient. Géobios, 30 (2): 179-192.

Gendrot, C., 1964. Contribution à l' etude de quelques foraminifères du Sénonien des Martigues (Bouches du Rhône, France). Eclogae Geologicae Helvetiae, 57: 529-535.

Görmüş, M., 1999. Pseudedomia hekimhanensis n. sp. from the late Campanian(?) to Maastrichtian of Hekimhan, NW Malatya, Turkey. Journal of Foraminiferal Research, 29 (3): 236-242.

Grimsdale, T.F., 1952. Cretaceous and Tertiary foraminifera from the Middle East. Bulletin of the British Museum (Natural History), 1: 221-248.

Hasmie, A., Rashwan, M., El Hedeny, M., Sharyari, S., Rahimi, S., Mansour, H., 2020. Facies development, palaeoecology, and palaeoenvironment of the Seymareh (Lopha Limestone) Member of the Gurpi Formation (Upper Campanian), Lurestan Province, SW Iran. Geological Journal. https://doi.org/ 10.1002/gj.3847.

Hoşgör, I., Košt'ák, M., 2102. Occurrence of the late Cretaceous belemnite Belemnitella in the Arabian Plate
(Hakkari. SE Turkey) and its paleogeographic significance. Cretaceous Research, 37: 35-42.

Henson, F.R.S., 1948. Larger imperforate Foraminifera of south-western Asia. Families Lituolidae, Orbitolinidae and Meandropsinidae. London, Monograph British Museum (Natural History): $127 \mathrm{p}$.

Hottinger, L., 2006. Illustrated glossary of terms used in foraminiferal research. Carnets Geol., 6(M02), CG2006_M02, 126 p.

Hottinger, L., Drobne, K., 1980. Early Tertiary conical imperforate foraminifera. Razprave IV. razr., SAZU, 22: $188-276$.

Keller, G., 2001. The end-Cretaceous mass-extinction in the marine realm: year 2000 assessment. Planetary and Space Science, 49: 817-830.

Khosrow Tehrani, K., Afghah, M., 2004. Microbiostratigraphy and microfacies study of the Tarbur Formation in northeast and Southeast of Shiraz. Geosciences, 12 (53): 74-87.

Khosrow Tehrani, K., Abyat, A., Afghah, M., 2008. Stratigraphy of lower part of Amiran Formation in N.W and S.E of Khorramabad. Journal of Geotechnical Geology (Applied Geology), 4 (2): 121-132.

Köylüoğlu, M., 1986. Güneydoğu Anadolu otokton birimlerin kronostratigrafisi, mikrofasiyes ve mikrofosilleri, T.P.A.O. Araştırma Merkezi, Eğitim Yayınlar1, 9: 1-53.

Lawa, F.A., Al-Omari, F.S., Al-Radwani, M.T., 1986. Restudy of the genus Gyroconulina Schroeder and Darmoian. Journal of the Geological Society of Iraq, 1(3): 77-82.

Loeblich, A.R., Jr., Tappan, H., 1987. Foraminiferal genera and their classification, Van Nostrand Reinhold, New York, 2 vol., 970 p., 847 pls.

Luger, P., Kuss, J., 1993. Late Cretaceous to basal Tertiary shallow water sedimentation in Northern Somalia. In: Thorweihe, U., Schandelmeier, H. (Eds.): Geoscientific Research in Northeast Africa: 443-447, Balkema, Rotterdam.

Meriç, E., 1974a. Note sur la presence de Pseudorbitolina marthae Douvillé dans les couches du Maestrichtien au Sud-Est de la Turquie. Istanbul Üniversitesi, Fen Fakültesi, Dergisi, Series B 39 (3-4): 219-222.

Meriç, E., 1974b. Sur la présence du genre Cyclopsinella dans les couches du Maestrichtien supérieur au sudest de al Turquie. Istanbul Üniversitesi, Fen Fakültesi, Dergisi, Series B 39 (3-4): 223-226.

Meriç E. 1988. Siderolites denticulatus Douvillé nin Elmalı (Antalya - Güneybatı Türkiye) yöresinde bulunuşu üzerine. Geological Bulletin of Turkey, 31: 29-32.

Meriç, E. and Görmüş, M., 2001. The genus Loftusia. Micropaleontology, 47, 1-71.

Munier-Chalmas, E., 1887. Sur la Cyclolina et trois nouveaux genres de foraminifères des couches à rudistes: Cyclopsina, Dicyclina et Spirocyclina. Compte Rendu des Séances de la Société géologique de France, 4(7): 30-31.

Neumann, M., 1964. A propos des genres Cyclolina d'Orbigny et Cyclopsinella Galloway. Revue de Micropaléontologie, 7 (1): 235-250. 
Neumann, M., 1978. Contribution à l'étude du genre Pseudorbitolina Douvillé 1919 (Foraminifère). Revue de Micropaléontologie, 20 (4): 197-205.

Ogg, J.G., Hinnov, L.A., 2012. The Cretaceous Period. In: Gradstein et al. (eds.), The Geologic Time Scale 2012. Elsevier Publ. Co.: 793-853.

Özer, S., Meriç, E., Görmüş, M., Kanbur, S., 2009. Biogeographic distribution of rudists and benthic foraminifera: An approach to Campanian-Maastrichtian palaeobiogeography of Turkey. Geobios, 42: 623-638.

Özkan, R., Altiner, D., 2019. The Cretaceous Mardin Group carbonates in southeast Turkey: Lithostratigraphy, foraminiferal biostratigraphy, microfacies and sequence stratigraphic evolution. Cretaceous Research, 98: 153-178.

Payandeh, S., Afghah, M., Shirazi, M.P., 2016. Biostratigraphy and lithostratigraphy of Upper Cretaceous sediments in Zagros Basin, South Iran. International Journal of Humanities and Cultural Studies, 2 (4): 1984-2001.

Parente, M., 1994. A revised stratigraphy of the Upper Cretaceous to Oligocene units from southeastern Salento (Apulia, southern Italy). Bolletino della Società Paleontologica Italiana, 33: 155-170.

Parente, M., 1997. Dasycladales from the Upper Maastrichtian of Salento Peninsula. Facies, 36: 91-122.

Pirbaluti, B.A., Ataabadi, M.M., Djafarian, M.A., Khosrow Tehrani, K., Afghah, M., Davoudi Farad, Z., 2013. Biostratigraphy and regional aspects of the Tarbur Formation (Maastrichtian) in Central Zagros, Southwest Iran. Rivista Italiana di Paleontologia e Stratigrafia, 119 (2): 215-227.

Piryaei, A., Reijmer, J.J.G., van Buchem, F.S.P., YazdiMoghadam, Y., Sadouni, J., Danelian, T., 2010. The influence of Late Cretaceous tectonic processes on sedimentation patterns along the northeastern Arabian plate margin (Fars Province, SW Iran). Geological Society London Special Publications, 330: 211-251.

Radoičić, R., 1979. Salpingoporella ubaiydhi, a new Senonian Dasyclad and some data about subsurface biostratigraphy of the western Iraqi desert. Bulletin de 1'Academie Serbe des Sciences et des Arts, Classe de Sciences Mathématiques et Naturelles, 68 (19): 97105.

Ramírez del Pozo, J., 1971. Bioestratigrafía y microfacies del Jurásico y Cretácico del Norte de España (región cantábrica). Memoria del Instituto Geológico y Minero de España, 78: 1-357.

Rahaghi, A., 1976. Contribution à I'étude de quelques grands foraminifères de I'Iran. Publications de la Société National Iranienne des Pétroles, Laboratoire de Micropaléontologie, Tehran 6: 1-79.

Rashidi, K., Schlagintweit, F., 2018. Dissocladella compressa n. sp., a new Dasycladale (green algae) from the Upper Maastrichtian of Iran. Arabian Journal of Geosciences, 12: article 247.

Rashidi, K., Schlagintweit, F., 2019. New data on some type-species of Maastrichtian-Paleocene Dasycladales (Green algae) from Iran. Part I. Pseudocymopolia Elliott. Carnets de Géologie, 19 (6): 97-111.

Rashidi, K., Schlagintweit, F., 2018. Zittelina? arumaensis (Okla, 1995) nov. comb. and Suppiluliumaella tarburensis n. sp. (Dasycladales) from the Upper
Maastrichtian of Iran. Arabian Journal of Geosciences, 11: 418.

Robles-Salcedo, R., Vicedo, V., Caus, E., 2018. Latest Campanian and Maastrichtian Siderolitidae (larger benthic foraminifera) from the Pyrenees (SE France and NE Spain). Cretaceous Research, 81: 64-85.

Robles-Salcedo, R., Vicedo, V., Parente, M., Caus, E., 2019. Canalispina iapygia gen. et sp. nov.: the last Siderolitidae Finlay, 1939 (larger foraminifera) from the upper Maastrichtian (Upper Cretaceous) of southern Italy. Cretaceous Research, 98: 84-94.

Sarı, B., Tasli, K., Özer, S., 2009. Benthonic foraminiferal biostratigraphy of the Upper Cretaceous (Middle Cenomanian-Coniacian) sequences of the Bey Dağlari Carbonate Platform, Western Taurides, Turkey. Turkish Journal of Earth Sciences, 18: 393-425.

Sartorio, D., Venturini, S., 1988. Southern Tethys Biofacies. AGIP: 238 p.

Schlagintweit, F., Rashidi, K., 2016. Some new and poorly known benthic foraminifera from late Maastrichtian shallow-water carbonates of the Zagros Zone, SW Iran. Acta Palaeontologica Romaniae, 12 (1): 53-70.

Schlagintweit, F., Rashidi, K., 2020. Broeckinella hensoni n. sp., a new larger benthic foraminifera from the upper Maastrichtian of Iran and a revision of the genus Broeckinella Henson, 1948. Acta Palaeontologica Romaniae, 16 (2): 57-67.

Schlagintweit, F., Rashidi, K., Barani, F., 2016a. First record of Gyroconulina columellifera Schroeder \& Darmoian, 1977 (larger benthic foraminifera) from the Maastrichtian Tarbur Formation of SW Iran (Zagros Fold-Thrust-Belt). Geopersia, 6 (2): 169-185.

Schlagintweit, F., Rashidi, K., Babadipour, M., $2016 \mathrm{~b}$. Orbitolinid foraminifera from the Late Maastrichtian of the Tarbur Formation (Zagros Zone, SW Iran). Acta Palaeontologica Romaniae, 12 (2): 29-46.

Schlagintweit, F., Studeny, M., Sanders, D., $2016 \mathrm{c}$. Clypeorbis? ultima n. sp. from the uppermost Maastrichtian of Austria: the youngest representative of the Clypeorbinae Sigal, 1952 (calcareous benthic foraminifera)? Cretaceous Research, 66: 163-170.

Schlumberger, C., Choffat, P., 1904. Sur le genre Spirocyclina Munier-Chalmas et quelques autres genres du meme auteur. Bulletin de la Société géologique du France, ser. 4, 4: 358-368.

Schroeder, R., 1985. Genre Simplorbitolina Ciry \& Rat, 1953. In: Schroeder, R., Neumann, M., (coords.). Les Grands Foraminifères du Crétacé Moyen de la région Méditerranénne. Géobios mémoire special, 7: 46-50.

Schroeder, R., Darmoian, S.A., 1977. Gyroconulina columellifera n. gen., n. sp., a complex ataxophragmiid foraminifer from the Aqra Limestone (Maastrichtian) of northern Iraq. Bolletino della Società Paleontologica Italiana, 16: 117-123.

Scotese, C.R., 2001. Atlas of Earth History. PALEOMAP Project, $58 \mathrm{p}$.

Septfontaine, M., Schlagintweit, F., Rashidi, K., 2019. Pachycolumella nov. gen., shallow-water benthic imperforate foraminifera and its species from the Maastrichtian and Paleocene of Iran. Micropalaeontology, 65 (2): 145-160.

Shigeta, Y., Nishimura, T., Nifuku, K., 2015. Middle and Late Maastrichtian (Latest Cretaceous) ammonoids 
from the Akkeshi Bay Area, Eastern Hokkaido, Northern Japan and their biostratigraphic implications. Paleontological Research, 19 (2): 107-127.

Sigal, J., 1977. Essai de zonation du Crétacé méditerranéen à l'aide des foraminifères planctoniques. Géologie Méditerranéenne, 4 (2): 99-108.

Smout, A.H., 1955. Reclassification of the Rotaliidea (Foraminifera) and two new Cretaceous forms resembling Elphidium. Journal of the Washington Academy of Sciences, 7: 201-210.

Solak, C., Tasli, K., Koç, H., 2017. Biostratigraphy and facies analysis of the Upper Cretaceous-Danian? platform carbonate succession in the Kuyucak are, western Central Taurides, S Turkey. Cretaceous Research, 79: 43-63.

Sirel, E., 2010. Haymana - Polatli Basin. $63^{\text {rd }}$ Geological Congress of Turkey, April 5-9, 2010 - Ankara, Field Excursion Guide Book, 1-29.

Temple, P.G., Perry, L.J., 1962. Geology and oil occurrence, SE Turkey1. AAPG Bulletin, 46 (9): 15961612.

Thibault, N., Husson, D., Harlou, R., Gardin, S., Galbrun,B., Huret, E., Minoletti, F., 2012. Astronomical calibra-tion of upper CampanianMaastrichtian carbon isotopeevents and calcareous plankton biostratigraphy in the Indian Ocean (ODP Hole 762C): Implication for the age of the Campanian -Maastrichtian boundary. Palaeogeography, Palaeoclimatology, Palaeoecology, 337-338: 52-71.

Van Gorsel, J.T., 1978, Late Cretaceous orbitoidal foraminifera. In: Hedley, R.H., Adams, C.G., eds., Foraminifera. Academic Press, London-New YorkSan Francisco, 3: 1-120.

Villalonga, R., Boix, C., Frijia, G., Parente, M., Bernaus, J.M., Caus, E., 2019. Larger foraminifera and strontium isotope stratigraphy of middle Campanian shallow-water lagoonal facies of the Pyrenean Basin (NE Spain). Facies, 65: 20.

Whittaker, J.E., Jones, R.W., Banner, F.T., 1998. Key Mesozoic benthic foraminifera of the Middle East. London, The Natural History Museum, 236 p., 107 pl. Wynd, J.G., 1965. Biofacies of the Iranian Oil Consortium Agreement Area. IOOC Report No. 1082, 89 p.

Zambetakis-Lekkas, A., Kemeridou, A., 2004. Loftusia cf. anatolica horizon in upper Maastrichtian limestones of the eastern Greece platform (Mount Ptoon, Boeotia, Greece): Palaeobiogeographical remarks. Bulletin of the Geological Society of Greece, 36: 792799. 